\title{
School Principals' Strategic Leadership to Optimize the Strengthening of Character Education Movement
}

\author{
Untung Waluyo*, Sudirnan Wilian, Muntari Muntari, I Wayan Karta \\ Graduate Program of Educational Administration \\ Universitas Mataram \\ Mataram, Indonesia \\ *untungwaluyo@unram.ac.id
}

\begin{abstract}
Based on the Presidential Decree No. 87 of 2017 on the so-called Mental Revolution, the Ministry of Education and Culture introduces the Strengthening of Character Education Movement (SCEM) that catalyzes character building among school children. Although this movement has been disseminated and trained to school teachers, principals, and school supervisors, the impact of the movement's training is not yet widely known due to the lack of research in this field. This study aims (1) to reveal the leadership strategies of the Selected Middle School Principals in Sumbawa Regency in optimizing the Strengthening of Character Education Movement, and (2) analyze problems faced by principals in carrying out their roles as strategic leaders in optimizing the implementation of SCEM. The collection of data used a qualitative research design with a multi-case study approach. Results of the study show all participants, principals of the selected schools, have developed various strategic leaderships to optimize the implementation of SCEM.
\end{abstract}

Keywords: character education, leadership strategy, school principal

\section{INTRODUCTION}

Through Presidential Regulation No. 87 of 2017, the Government of Indonesia introduces the concept of strengthening character education based on religious values, nationalism, integrity, independence, and cooperation. These values are emphasized in President Joko Widodo's mental revolution dictum and are outlined in a national initiative called the Strengthening of Character Education Movement (SCEM). Through the Ministerial Decree No 20 2018, the Ministry of Education and Culture stipulates that every elementary school and junior high school is obliged to implement the initiative to realize the Mental Revolution dictum. Several manuals and training modules for implementing the SCEM movement have been published for this purpose.

Ideally, the emergence of such a movement certainly provides a springboard for school principals and teachers to strengthen the implementation of character education. They have greater opportunities to combine both cognitive intelligence (IQ) and spirituality intelligence (SQ) through integrated formal curricular, intra-curricular, and extracurricular activities. Through a series of blended learning activities, students are expected to be able to think and practice decent morals and mutual respect to teachers, principals, staff, and other fellow students. These values of morality and spirituality are the main assets for building the nation's characters that need to be instilled early in the students' lives. In the long run, these students will acquire not only the rationality of thought but also the morality of an action, which rests on the virtuous deeds.

The current conditions in the field, however, indicate that the notion of character education remains problematic in some ways. Many teachers get difficulties to integrate character education in the subject matters they teach [1]. The same thing happened to school principals and other stakeholders [2]. Although the Government of Indonesia has published manuals and instructions for implementing SCEM in schools, many teachers and principals lack understanding of the concept of integrating character education into the subject matters they teach. Faced with exhausting teaching and administrative tasks, both teachers and principals often carry out the policy of strengthening character education movement in the manner of "business as usual". The researcher goals by conducting the current study are (a) to reveal the leadership strategies employed by principals of the selected junior high schools in Sumbawa Regency about the implementation of the policy of Strengthening Character Education Movement in schools, (b) to analyze the problems faced by principals in carrying out their roles as strategic leaders in implementing the movement to strengthen character education in schools effectively.

Regarding the above research objectives, two main points are underlying the importance of the current research. First, although the SCEM movement has been introduced to schools and trained to teachers and principals, the impact of the training on their ability to integrate character education into school subjects is not widely known because research results in the field are not well disseminated yet. Second, several empirical facts in the area show that many teachers, principals, and other stakeholders still do not maximize their roles and duties in implementing SCEM. The implementation of the SCEM movement in schools results seen as a burden; thus, the school management runs the initiative on a superficial basis. Through this study, the researchers, therefore, intend to explore the principals' abilities in maximizing their leadership capacities strategically to integrate SCEM into the school curricular activities. Also, the researchers attempt to find patterns or 
models for implementing SCEM movements in schools that sustain the maintenance of both nationalism and moral values.

Kools and Stall, as stated in Acetylena [3], suggested teachers, principals, and other stakeholders must learn to build their abilities through the development of collective learning to create a profound change in schools. Real change can only occur if every school stakeholder feels committed to creating change collectively. If the school can become an arena of shared knowledge within a school organization, then everyone will contribute to shared change through the creation of a healthy and productive learning culture within the school organization. In this study, the researchers adopt three major postulates of their theories to look at the phenomenon observed, i.e.: (a) right leader, (b) right people, and (c) right behaviors.

As regards the term right leader, Kools and Stal, as stated in [3], explained that a principal is the highest leader in a school. To change the culture of the school, he must start from himself. Thus, he must have a vision and a willingness to change the school culture into the better one. He must become an example for the people around him. He must be able to communicate his vision and continue to encourage the development of the values of collective learning in his organization. For this reason, he must help stakeholders in the school understand the direction and purpose of their leadership through strong communication with the people they lead.

A visionary principal should be able to involve all teachers and staff to build a healthy school culture. In other words, he must be able to persuade all school components to work with him. When all teachers and staff have indiscriminate treatment, they will participate voluntarily and are not afraid of making mistakes. They will see errors as part of their learning journey. In such a school, the principal usually gets maximum support from his associates as they feel appreciated to explore new ideas for school benefits. When all school components have a convergent vision, the principal has created the right people that sustain healthy learning organization for the improvement of school performance.

The third component deals with the right behaviors. The term behavior in this context refers to the total attitudes of people involved in creating school culture. In general, teacher's and staff's change of behavior in school varies individual to individual, depending on their abilities to adapt to the leadership model introduced by the principal. Frequently, there are teachers and staff who are willing to change their behaviors to fit in the school norms introduced by the principal to achieve a shared professional identity. However, some teachers maintain their old practices and feel uncomfortable with the changes. The principal usually faces resistance from them when he attempts to introduce the new norms. In a learning organization, a visionary principal will have work commitment with these people and be open to accepting them unconditionally. This attitude often encourages the resistant group to be eventually willing to change their negative behaviors into the right ones [4].

Together the three components help principals build a commitment among teachers and staff to create a change in school as they feel comfortable and happy to work with their leader [5]. In schools that implement learning organizations, the principal's burden in dealing with the complexity of problems will reduce greatly. Likewise, it is true with other stakeholders. A school principal, who shares his vision with his staff, generally builds the culture of his school organization consistently as they are willing to allocate the available resources and communicate his strategic views on an ongoing basis. Regardless of his important position or high hierarchical authority, a visionary leader usually emphasizes more on collective attainment rather than his accomplishment.

Strategic leaders usually like challenges and work in highly complex environments. In a school like this, such a principal typically are capable of solving problems through teamwork development and implementing strategic plans into practice. Every action he takes to solve problems rests on his reasonable efforts to create a school as a learning organization for every individual. Principals of this kind are aware that everyone is an important component and can directly influence the results to be achieved by the school. Recognizing its weaknesses, a strategic school principal usually involves more people in managing the school and available resources. The ideas about visionary leadership are in line with research findings in the field of leadership, such as Seashore and Mintrop, [5], Knapp and Feldman [6], Bredeson [7], Louis and Robinson [8], Klar, Hammonds, Buskey and Huggins [9], and Watson [10]. The influence of principal visionary leadership had pervasive implications on the development of school culture. Senge [11] and Deeboonmee [12] found that good principal leadership was able to nurture teachers to develop professionalism, positive norms, and values and to increase teachers' job satisfaction.

To sum up, the current literature showed that some interrelated factors influenced school principals in implementing strategic leadership and creating school culture. In this study, the researchers employed three essential theoretical components, i.e., (1) right leader, (2) right people, and (3) right behaviors. These are to look at how the principals of the selected junior high schools in the Sumbawa Regency develop strategic leaderships and school culture to implement the policy of Character Education Strengthening Movement.

\section{METHODS}

This research was conducted in the Sumbawa Regency of West Nusa Tenggara Province. The reason for choosing the location is because the Sumbawa district, as one of the regions in NTB Province, became a piloting area for conducting socialization and training of SCEM. Thus, the assumption used is that schools in this district have implemented SCEM in junior high schools. For this reason, the researchers wanted to explore more about the implementation of character education in junior high schools in the Sumbawa Regency and the strategic leadership approach models used by school principals in the selected schools. This study chose four schools to represent schools in 4 sub-districts in Sumbawa Regency.

Various researchers in the field of leadership and the application of national policies, especially in the field of education, commonly use a qualitative approach to account for or describe the observed phenomena. The same is true with the 
current study. The researchers chose to use a qualitative approach with the consideration that the issue of the principal's strategic leadership and its impact on the implementation of the policy has a complexity that cannot be represented by statistical figures alone. To better understand the complexity of the problems faced by school principals in implementing policies in schools, they lead qualitative research with a multiple case study approach is required. Punch [13] explains that the case study approach is appropriate to be used to reveal the complexity of phenomena in education through the use of various data sources. The research design chosen allows the researchers to explore some selected schools in the Sumbawa Regency in implementing the SCEM and the strategic leadership models employed by school principals in maximizing the stakeholder participation in line with the mandate of The Ministerial Regulation of Education No 20 2018. Thus, the expected results of this study are to be able to outline in more deeply the factual problems of policy implementation in the field of education. Through this research study, a description of the principal's strategy in implementing the SCEM policy revealed in detail.

The procedures and stages of activities carried out in this study include (a) collecting preliminary data on the application of the SCEM movement in selected junior high schools in the Sumbawa Regency through documentation studies related to the implementation of the SCEM movement, (b) conducting interviews with school principals and focused group discussion activities with teachers to capture their views on the principal's strategic leadership in implementing the SCEM movement, and (c) conducting analysis related to the patterns/models of SCEM implementation in schools. Data obtained from various sources were analyzed using qualitative analysis procedures suggested by Miles and Huberman [14]. This qualitative analysis procedure includes the process of data reduction, data presentation, and drawing conclusions and verification. Data obtained from document studies were grouped and sorted out according to the emerging themes. Likewise, data from the interviews were also sorted based on ideas and categories that emerged. In essence, data relevant to the topic are grouped in sub-themes until they experienced saturation. Data triangulation used in this analysis was to obtain or strengthen the level of reliability of the data. The data analysis result revealed a description of the success factors and impeding factors for the implementation of the SCEM movement. Also, a lesson learned models from the selected schools in the Sumbawa district obtained.

\section{FINDINGS}

The results of this study revealed that all participating principals had developed three models of leadership with their uniqueness. The researchers labeled the first model as community-participatory leadership. This label attributed principals who had a deep understanding of their duties and responsibilities as the front-liners of the implementation of character education movement. These principals admitted that they would not be able to implement the change without the active participation of school stakeholders. To exemplify, participant-1 agreed, "I cannot work alone. I always welcome anyone to share their knowledge and experience about enhancing character education in our school. Periodically, I invite school stakeholders to participate in evaluating the course of character education in my school" He further exemplified how he worked collaboratively with parents and members of the community in nurturing students to become members of law-abiding society. For that reason, he regularly involved members of the community, formal institutions, and parents in planning activities for the implementation of character education in his school. He explained, "I involve the police, immigration officers, members of the army to discuss with students about traffic regulations, legal issues, drug abuse, and so on. Our students seemed to enjoy having dialogues with them" Participant-2 also introduced a similar approach to implement SCEM in his school. Before submitting a disciplinary school regulation, he invited parents and formal and informal leaders in the community to get positive feedback from them. He said, "I believe when everything is clearly explained, students and their parents will understand the reasons for our acts". By doing so, his students received firsthand information from the right parties and knew the logical consequences when they with legal problems faced.

According to several teachers interviewed in both schools, their principals demonstrated a similar ability to create a positive school atmosphere for teachers and students. One teacher explained, "Our principal [participant-1] has introduced a hand-shaking habit between students and teachers when they arrive at school every morning. These habits meant to create warm-relationship and punctuality among us. He always comes in time and stands in the school gate with greetings and a warm smile. Another teacher commented, "As he is always punctual, we feel embarrassed if we come late," most teachers expressed similar comments. They admitted that their principal [participant-2] liked to talk personally when his teaching staff experienced problems with their teaching duties. "He is exemplary, a dedicated leader who respects his staff and helps them when they face problems", said another teacher. In general, most teachers interviewed mentioned some similar concepts developed by both principals about the quality of their leadership, such as respectable, hard-working, motivating, and committing to duties, compassionate, creative, and innovative. By developing such qualities of leadership, both principals had received positive supports and voluntary participation from the school stakeholders and members community in enhancing the implementation of SCEM.

The second leadership model was labeled as a religionbased model. From the interviews, the participant- 3 believed that education could not be separated from spirituality matters. He asserted, "To nurture character education in my school, I involve the practice of spirituality to create good moral conduct. I introduce the Quran recitation program: one day one verse for Muslim students" According to participant-3, he also accommodated students and teachers from different religions/beliefs to run similar programs. He explained, "The point is how we build our children's mentality following their Indonesian characters ... they are polite, mutually cooperative, and consistent in practicing the religious teachings at school and home". He further commented when children and teachers had a deep understanding of their religions and practiced them 
as well in school, and at home, in the long run, the respectable characters as mandated by the goal of national education could be well achieved.

In general, the teachers interviewed asserted that participant-3 treated them as equal colleagues regardless of differences in religious background. Every morning before the teaching and learning process, teachers and students had a short sacred assembly based on each of their religious beliefs. In this relation, one of the teachers asserted, "Our principal emphasizes that we, teachers, consistently become role models for our students in carrying out religious practices". Likewise, another teacher gives a similar comment. "Here, teachers from other religious beliefs actively take part in carrying out religious assembly because of the school principal's nondiscriminatory policies". Many of the teachers interviewed noted that the nature of their principal's leadership made them feel accommodated, respected, and well-accepted.

The third model is labeled as a servant leadership model. The study revealed that participant- 3 had developed a broad vision in managing SCEM. He believed that the key success of leading teachers in implementing SCEM was to provide a role model consistently. In this regard, he said, "If I want to get supports from teachers to run SCEM successfully, I must talk less, listen more, and persuade them to be committed to our school vision. I am ready to help them anytime" He further informed that he rarely sat down behind the desk. He went around the school to make sure everything was okay before classes began. "My job is only to help teachers when they are facing problems," he said. "If I found problems with teacher teaching performance, I persuade them to do self-assessment and self-reflection. I am always open to accepting their complaints. At this point, some personal traits of leadership developed by the principal could be drawn from the data, i.e., commitment to duties, help for others, open communication, persuasion, and acceptance. With such personal traits, the principal exercised his leadership to direct teachers to cultivate their awareness to implement SCEM.

Interviews with teachers show data consistency. Most teachers felt positive about their school principal's leadership style, which prioritized help for others. One of the teachers exemplified, "Our principal often takes surprising initiatives. He enters classes whose teachers are late in the first learning hours" Another teacher concurred, "I have experienced something like that. I was very embarrassed and promised myself not to be late again. Our principal slowly builds a positive school culture together" These findings signify that teachers respected their principal because of his exemplary humble characters.

Interestingly, most teachers declared that they felt satisfied with the present leadership models practiced by their principals. One of the teachers stressed: "I feel respected with my present principal because he does not put himself too high" Two other teachers shared similar experiences. They felt the current principals were exemplary good role models.

It was apparent from the data that most teachers experienced new learning endeavors to participate in SCEM due to the positive support from their principals. Such positive support occurred among the majority of the teachers. The nurturing process shared by their principals seemed to spread systematically because of their strategic leadership practices. Teachers were able to recognize the needs for creating a positive whole-school culture that supported SCEM practices. At this stage, the practice of strategic leadership developed by those principals showed some impact on the quality of teachers' willingness to support the current implementation of SCEM. The adoption of such leadership seemed to have made teachers feel respected and valued. Most teachers expressed their satisfaction and appreciation positively with the current school principals. These teachers reported experiencing encouraging communication with their principals and their colleagues. They admitted that there was information sharing among colleagues concerning SCEM. They found their principal has willing to share his knowledge and wisdom about how to nurture moral education both at school and at home.

Despite such positive responses, some participants expressed that they felt sufficiently insecure and afraid of giving comments about the current school leadership. The researchers then asked to interview them outside their schools. From these participants, some problems with the implementation of SCEM in their schools identified late. In this relation, two major themes appeared from their responses, i.e., (a) resistance to accept change, and (b) inadequate training supports from the government.

As regards the first theme, peer resistance to accept a change, some teachers testified that not all of their colleagues were supportive of the principal's efforts to implement SCEM in schools. The data identified that some senior teachers showed resistance to a change. One senior teacher said, "I am supposed to integrate character education in my subject, but I do not do it. I do not know how. I just teach the way I used to teach" Another senior teacher conceded that the source of his resistance lied in his own belief concerning character education and his lack of communication with other staff members. Some other senior teachers concurred. In short, the findings show that teachers' resistance to accepting a change of practice was attributed to two major factors, i.e., teachers' ages and their hierarchical status. These factors seemed to be the key points that trigger their resistance for a change.

The second theme deals with the inadequacy of training support on SCEM from the local education office. Most teachers remarked that the implementation of SCEM still faced hurdles due to the lack of support from the local education office of the provision of professional development in the implementation of SCEM. One of the participants stated, "Formally, the implementation of SCEM in our school has never been addressed by the local education office. So far, we just carry out the movement based on the information we received from the principal. Thus, we run the program based on our interpretation" These teachers also informed that they never took part in any professional training from the local education office. One of them commented that she and most of her colleagues ran SCEM without a clear guideline. She contended, "Surely we implement the program, but we do not 


\section{REFERENCES}

know how to vary the activities and to evaluate character education". All these quotes denote that the implementation of SCEM did not run maximally at the school level due to the lack of training concerning SCEM activities and its method of evaluation.

This above finding suggests that the school principals need to listen to these silent voices. They should consider focusing their attention on the unheard voices. It was apparent from the data that the principals needed to introduce different approaches to deal with these people. They wanted the school principals to recognize their difficulties in adjusting to their leadership style. They articulated that they needed some assistance to deal with something they were not familiar with clearly.

\section{CONCLUSION}

To conclude, the results of the study suggest that school leadership played a significant role in maintaining the creation of a healthy leadership atmosphere so that schools can run SCEM as expected. The research shows that when principals shared leadership with members of school milieu and developed a healthy working relationship with all teachers. The course of their synergy action and conflict may not necessarily happen. It was clear from the data the school principals could manage their resources to focus their energy altogether on the targeted future goals due to the quality of their strategic leadership. To deal with leadership complexity, principals of the selected schools developed strategic leadership models to cope with SCEM implementation: (1) Community-participatory leadership model, (2) Religion-based leadership model, and (3) Servant leader leadership model. Some novel approaches were practiced by principals to orchestrate the implementation of the SCEM movement. Regardless of the positive impact of the principal leadership models, problems are still identified to impede the undertaking of SCEM, i.e., peer reluctance to support the principals to run SCEM movement and the lack of supports from both government and the community.

\section{ACKNOWLEDGMENT}

The authors gratefully acknowledge DIPA BLU research and travel grant for Master Program, University of Mataram, 2019 .
[1] Triatmanto, "Tantangan Implementasi Pendidikan Karakter". ("The Challenge of Implementing Character Education). Cakrawala Pendidikan, Special Edition of UNY Anniversary, pp. 187-203, 2010 available at https://core.ac.uk/download/pdf/11061988.pdf

[2] S. Acetylena,. "Analisis Implementasi Kebijakan Pendidikan Karakter Di Perguruan Taman Siswa Kecamatan Turen Kabupaten Malang”.(An Analysis of the Implementation of Character Education in Taman Siswa School in Turen Sub-district, Malang Regency). Jurnal Kebijakan dan Pengembangan Pendidikan 1, 1, pp. 55-61, 2013Kools, M. and Stoll L. (2016), "What Makes a School a Learning Organisation?", OECD Education Working Papers, No. 137, OECD Publishing, Paris. http://dx.doi.org/10.1787/5jlwm62b3bvh-en

[3] H. Widodo. "Strategi Kepala Sekolah dalam Mengembangkan Pendidikan Karakter di Sekolah Dasar Muhammadiyah Sleman" (The Principals' strategies in Developing Character Education in Sleman Muhammadiyah Primary School). Metodik Didaktik: 13, 2, pp. 69-80, Januari 2018. Available

http://ejournal.upi.edu/index.php/MetodikDidaktik/article/view/8162/60 82

[4] P. Senge, Schools that learn: A Fifth discipline Field-book for Educators, Parents and Everyone who Cares about Education. New York: Crown Business. 2000

[5] L.K. Seashore, and H. Mintrop, "Bridging accountability obligations, professional values and (perceived) student needs with integrity". Journal of Educational Administration, 50, pp. 695-726, 2012.

[6] M.S. Knapp and S. B. Feldman, "Managing the intersection of internal and external accountability: Challenge for urban school leadership in the United States". Journal of Educational Administration, 50, pp. 666-694. 2012.

[7] P.V. Bredeson, "The school principal's role in teacher professional development". Journal of In-Service Education. 26: pp. 385-401. 2000

[8] K.S. Louis and V.M. Robinson, "External Mandates and Instructional Leadership: School Leaders as Mediating Agents". Journal of Educational Administration, 50, pp. 629-665, 2012.

[9] H.W. Klar, H.L. Hammonds, F.C. Buskey, and K.S. Huggins, "Fostering the capacity for distributed leadership: A post-heroic approach to leading school improvement". International Journal of Leadership in Education. 19: pp. 111-137, 2016.

[10] M. Watson, "Long Term Effect of Character/Moral Education". Journal of Research in Character Education . 4, pp 1-18. 2006.

[11] P. Senge, C. Roberts, R. Ross B.J. Smith and A, Kleiner, The fifth discipline field-book. London: Century Pub. 1994.

[12] W. Deeboonmee and W. Ariratana, Relationship between Strategic Leadership and School Effectiveness. Procedia - Social and Behavioral Sciences. 112, 982-985. 2014.

[13] K.F. Punch, Introduction to Research Methods in Education. London: Sage Publications, 2009.

[14] M.B. Miles, M. B., and A.M. Huberman, Qualitative data analysis: An expanded sourcebook. Thousand Oaks: Sage, 2005. 